\title{
Mixed Ownership Structures and Firm Performance in China Listed Firms
}

\author{
Xiaolou Yang ${ }^{1}$ \\ ${ }^{1}$ Youngstown State University, Youngstown, USA \\ Correspondence: Xiaolou Yang, Associate Professor of Finance, Youngstown State University, Youngstown, OH, \\ 44555, USA.
}

Received: August 4, 2017

Accepted: August 21, 2017

Online Published: September 16, 2017

doi:10.5430/ijfr.v8n4p80

URL: https://doi.org/10.5430/ijfr.v8n4p80

\begin{abstract}
China has achieved impressive economic growth since market reforms. The design of appropriate compensation structures is imperative so as to incentivize top managers, but little research has been done to examine the top management compensation structure in China. This study investigates how listed firms in China relate executive compensation to their firm performance and how such relationships are influenced by firm ownership structure. The results provide evidence showing strong link between compensation and performance varies across firms with different ownership structure. Private ownership enhances the link between firm performance and top CEOs compensation, while government ownership weakens executive pay-performance relation and thus makes the firms less effective in solving the agency problem between shareholders and management. It suggests enterprise reform in China will need to be supplemented by change in ownership structure in order to ensure fully success by transforming its State Owned Enterprises (SOEs) to corporations in the direction of converting state shares to public shares.
\end{abstract}

Keywords: government structure, firm performance, executive compensation

\section{Introduction}

Compensation and incentive structures in China' listed firms are crucial in determining the success of enterprise reform in China, yet they are not well understood so far. The design of appropriate compensation structures is imperative so as to incentivize top executives. However, there is little research on how these corporations operate. However, although listed firms in China has rapidly grew, significant portion of these firms are still controlled by the government. In other words, government shares still dominate the ownership structure in most firms. This casts doubt on efficiency as well as effectiveness of China privatization reform. It's therefore crucial important to explore how these firms align top executive compensation and firm performance and how such relation are impacted by the ownership structure.

China enterprise reform began in 1978 as part of the government's effort to help SOEs raise capital and reduce debt burden. This process has taken through several stages. Prior to 1978, state owned enterprises have dominating control over the firm activities and profits were remitted to the government and deficits were also covered by the government. Since 1978, profit retention and sharing schemes were introduced, firms had more autonomy. These schemes were converted to a contract responsibility system, which emphasized the separation of ownership from management. For the first time, the responsibilities, rights, and interests of the state authorities and firms were clearly enunciated as contracts (Sah, 1990).

Before the SOEs reform, there was a highly structured pay scale system that all profits were repatriated to the state. There was no incentive payment scheme to motivate managers. In which case, managers were representatives of government. At the end of 1990, the Shanghai Stock Exchanges was established and shortly after that the Shenzhen Stock Exchange started operating in early 1991 and the first Chinese company went public in 1991. Since Chinese Communist Party's (the CCP) $14^{\text {th }}$ congress with adoption of a modern corporation system that resembles the west, there was a rapid development of China's stock market. This led to a rapid increase in the number of firms listed in the two stock exchanges in China. The listed firms are regulated by Chinese Securities Regulatory Commission (CSRC) trading shares in Shanghai Stock Exchange and Shenzhen Stock Exchange. Although the corporate structures of the listed firms are similar to those in the west countries, ownership structure is very different due to the 
dominance of government ownership in China listed firms. The government dominates the ownership and control of many firm financial and operational activities.

The dominance of government ownership is associated with unique pay system for top managers in the listed firms. First of all, executive compensation in the private firms based on performance measure such as profit, sales growth, ROA etc., while for state controlled firms, compensation mainly based on growth rate of state-owned asset along with non-financial measures.

Previous studies on pay-performance in China listed firms before the stock market era found positive linkage of accounting measure to CEOs compensation (Roves et al., 1995) Extensive empirical research in Britain, the U.S., and elsewhere, has resulted in mixed findings on the pay-for-performance relationship. Coughlan and Schmidt (1985), Mehran (1995), Murphy (1985, 1988) and Yang (2010), among others, report a positive relationship. Jensen and Murphy (1990) also find a positive association between CEO pay and stock returns, but they caution that the sensitivity of pay to performance is so small that it is unlikely to be much of an incentive for managers. Other studies have found very weak or no pay-for-performance link (Gregg et al., 1993; Conyon et al., 1995; Zhou, 1999). More recent studies that include the benefits from stock options in top management pay, find positive relationship between pay and stock returns (Conyon and Murphy, 2000; Main et al., 1996). This finding is not surprising given the link between stock option benefits and stock returns. It should be recognized, however, that these studies cover periods when stock prices have been rising quite sharply and the relationships may be different in times of stock market malaise.

This paper complements these early pre-stock market studies with two principle aims. First, by using data on executive compensation in China's listed firms, I provide rigor estimations on pay-performance sensitivities and elasticities. Second, although significant portion of China listed firms are state controlled, there is a considerable variation in ownership structure in the process of China privatization reform, this study exam, the first time, how ownership structure influences pay-performance relations and exam the quality of corporate governance in China listed firms by accessing the relation between executive incentives, risk-taking and firm performance measured by both ROA and stock return. Systematic research outside the US on executive compensation is still in its infancy, especially in emerging markets. This paper contributes to the literature on executive compensation in emerging markets. It is the first to look at pay-performance sensitivities and elasticities for listed firms in China.

In this study, I applied three-simultaneous-equation using 3 Stage least Square (3SLS) method in which compensation measures and firm risk/performance are all treated as endogenous variables and jointly determined. This approach could avoid spurious inferences in OLS thus provide unbiased estimates of standard errors (Sawa, 1969).

The structure of the paper is as follows. In Section 2, I provide methodology and model, while reviewing the relevant literature. Section 3 describes data, followed by Section 4, where the main results are presented. Section 5 concludes by summarizing the findings and discussing policy implications.

\section{Methodology}

Many empirical research measure the compensation structure use the ratio of stock option to total compensation as the measure of option based compensation. Such compensation measures, however, cannot precisely capture risk-taking incentives of managers induced by their compensation schemes. In this study I obtain a more precise measure of compensation by including both vega and delta into empirical models, which allows to isolate the effect of vega and delta. Except the study by Rogers (2002) and Coles et al. (2006), prior studies tend to focus on one dimension of compensation structure, such as delta or vega, without controlling for the other. However, the mix of vega and delta are likely to have substantially cross-sectional differences and both affect risk-taking behavior (Guay, 1999). Therefore, any analysis that examines the relation between risk-taking/firm performance and vega should control delta.

Moreover, very few studies on the association between risk and compensation structure allow estimation of the underlying causal relationships. Rogers (2002) questions if a positive association between stock return volatility and vega indicates that vega is used to implement high-risk decisions, or does it suggest that some underlying and omitted primitive factor drives the association between vega and volatility? Similar questions arise over the association between vega and other managerial decisions. All of these examples imply that causation is likely to run in both directions for vega and delta. It is critical to account for how investment choices and characteristics of the managerial compensation schemes are jointly determined. When both compensation characteristics and managerial decisions are endogenous, OLS results are not appropriate because the orthogonality assumption is violated, and the 
use of OLS leads to biased and inconsistent parameter estimates. The usual $\mathrm{t}$ and $\mathrm{F}$ tests for these parameters are no longer valid.

Vega is defined as the change in the dollar value of the executive's wealth for a one percentage point change in the annualized standard deviation of stock returns. Delta is defined as the change in the dollar value of the executive's wealth for a one percentage point change in stock price. Guay (1999) shows that option vega is many times higher than stock vega. Rajgopal and Shevlin (2002), Rogers (2002) and Coles et al. (2006) adopt the same approach. The vega and delta calculations follows Guay (1999) and Core and Guay (2002a). Vega is computed as the partial derivative of the Black-Scholes option pricing model with respect to stock return volatility as follows:

$$
\frac{\partial(\text { option } \quad \text { value })}{\partial(\text { stock volatility })}=e^{-d T} N^{\prime}(Z) S T^{(1 / 2)}
$$

Where $N^{\prime}$ is the normal density function. The dollar value measures the magnitude of managers' incentives of risk-taking. Indeed, the higher the sensitivity of the manager's compensation to risk the more he/she gains from increasing risk. Therefore, this measure captures directly the incentives of executives to increase risk. The sensitivity with respect to a $1 \%$ change in stock price, delta, is partial derivative with respect to stock price:

$$
\frac{\partial(\text { option value })}{\partial(\text { price })}\left(\frac{\text { price }}{100}\right)=e^{-d T} N(Z)\left(\frac{\text { price }}{100}\right) \text {, }
$$

In this study, in order to avoid spurious inferences and to isolate causation, I apply 3 stage least square (3SLS) method folloId by Coles et al. (2006) and Yang (2010), where one of the interested variables (firm risk, security underwriting, mortgage loan or write-offs), vega and delta, are contemporaneously determined to disentangle the causality betIen compensation incentives and risk-taking. I used the model to testing: (1) How board and ownership structure affect firms' CEOs' incentive compensation, or vega (controlling for delta), and (2) How equity-based compensation, vega and delta, affect firms' risk-raking investments.

In order to assess the relation between ownership structure, vega and firm risk, I apply a three-simultaneous-equation using a 3 Stage Least Square (3SLS) method in which vega, delta, and firm risk are all treated as endogenous variables and are jointly determined. While I focus on vega as the primary explanatory variable, all model specifications in this study include both delta and control variables based on current literature. I control for firm size, stock prices, long-term debt ratio and growth opportunities (Servaes, 1994; Bhagat and Ilch, 1995; and Opler et al., 1999). An important reason to include control variables is to represent forces that drive both vega and delta together with investment or financial strategies. The regression equations include,

$$
\begin{aligned}
& \text { FirmRisk }_{i t}=\alpha_{0}+\alpha_{1} \text { vega }_{i t}+\alpha_{2} \text { delta }_{i t}+X_{i t}+\mu_{i}+v_{t}+\varepsilon_{i t} \\
& \text { Vega }_{i t}=\beta_{0}+\beta_{1} \text { FirmRisk }_{i t}+\beta_{2} \text { Delta }_{i t}+Y_{i t}+\eta_{i}+\delta_{t}+\zeta_{i t} \\
& \text { Delta }_{i t}=\gamma_{0}+\gamma_{1} \text { FirmRisk }_{i t}+\gamma_{2} \text { Vega }_{i t}+Z_{i t}+\varphi_{i}+v_{t}+\xi_{i t}
\end{aligned}
$$

where $X_{i t}$ is the explanatory variables for firm risk equation, including firm size. $Y_{i t}$ is the explanatory variables for the equation of vega, including firm size, growth opportunities (market value to book value of assets) and long-term debt ratio. $Z_{i t}$ is the explanatory variables for the equation of delta, including firm size and stock price. The reasons for choosing these variables as instrument variables are, first, they are informative for the dependent variables, and second, these variables are exogenous in the system equations. $\mu_{i}, \eta_{i}$ and $\varphi_{i}$ represent a

firm-specific effect, $v_{t}, \delta_{t}$ and $v_{t}$ represent a cross-sectional time-specific effect, and $\varepsilon_{i t}, \zeta_{i t}$ and $\xi_{i t}$ capture 
the measurement errors. In the following sections, the 3SLS models are specified in a similar way, where the dependent variable in the first equation, firm risk, is replaced by one the of investment variables (security underwriting, mortgage loan, and write-offs).

\section{Data}

China has started to report executive compensation data since1998. Listed companies have been required to disclose top executive compensation. Required compensation disclosures in the annual report are total remuneration to the members of the board of directors, the supervisory board, and senior management. Compensation of the highest paid executive in the company is also disclosed. The pay is the total cash compensation and includes base salary, bonuses, and commissions. Bonus pay is incentive payment tied to firm performance. I applied a simulation approach to generate the sample include all non-financial firms which are listed on the Shanghai and Shenzhen stock exchanges. In line with other studies, I exclude firms in financial sector. Executive compensations are estimated on shareholdings of the three largest shareholders, board size, and board compensations. The analysis is based on information extracted from annual reports over the 1998-2006.

Table 1. Data descriptive statistics

\begin{tabular}{llllll}
\hline Variables & Mean & Median & Min & Max & Std \\
\hline Compensation & & & & & \\
\hline Vega & 12.21 & 13.49 & 0.08 & 106.32 & 34.16 \\
Delta & 11.21 & 9.36 & 0.38 & 128.39 & 36.51 \\
Cash compensation (000s) & 452.56 & 462.19 & 87.33 & 2528.42 & 862.33 \\
Performance & & & & & \\
ROA & 1.58 & 3.24 & -45.33 & 37.89 & 13.22 \\
Stock return (RETURN) & 39.88 & 46.35 & -20.33 & 358.92 & 79.41 \\
\hline Firm characteristics & & & & & \\
\hline Profit (000,000s) & 45.67 & 32.35 & -689.72 & 1356.32 & 138.21 \\
Sales (000,000s) & 889.16 & 357.29 & -52.33 & 8675.42 & 829.13 \\
Assets (000,000s) & 1513.46 & 963.22 & 135.47 & 20583.32 & 1046.79 \\
Market to book ratio & 2.58 & 2.36 & 0 & 12.43 & 2.79 \\
Debt ratio (DEBT) & 0.13 & 0.15 & -0.39 & 6.18 & 0.26 \\
\hline Governance structure & & & & & \\
\hline State ownership (GOV) & 0.52 & 0.69 & 0 & 1 & 0.47 \\
Ownership concentration (CONC) & 0.25 & 0.28 & 0.05 & 0.92 & 0.63 \\
Foreign shares (FSHARE) & 0.18 & 0.05 & 0 & 1 & 0.59 \\
Board size (BOARD) & 9.46 & 8.32 & 6 & 25 & 2.81 \\
\hline
\end{tabular}

Table 1 reports descriptive statistics on compensation, firm characteristics, and other control variables. The mean cash compensation is RMB452,560/US64,651. Mean and median vega are 12.21 and 13.49. While mean and median delta are 11.21 and 9.36. Means stock return during sample period is high, which is $39.88 \%$ while is associated with high standard deviation of 79\%. Debt to ratio is on average low. Mean and median debt ratio are $13 \%$ and $15 \%$. State ownership takes more than a half of firms. Ownership concentration on average is $25 \%$. Foreign shares take on average of $18 \%$ with median of 5\%. Board size on average around 9.

\section{Empirical Results}

In this section I assess the relation between executive incentives and firm risk-taking investments. I examine the relation among three variables: vega, delta, and firm risk. To address the possibility that there are other omitted variables, all specifications throughout include both industry (two-digit SIC) fixed and year effects. I include all of the endogenous variables on the right-hand side.

Table 2 reports the estimates of three-simultaneous-equation model (3SLS). The jointly determined variables are vega, delta, and firm risk. Here and throughout, reported $t$-statistics are based on robust standard errors. I draw independent 
variables from the prior literature (e.g., Bizjak et al., 1993; Guay, 1999; Core and Guay, 1999) for vega and delta. First, vega is significantly positively correlated with delta, which is consistent with prior literature. Second, the coefficients on firm risk is positive and significant different from zero. It implies that higher level of risk increase the managerial incentive in compensation, as reflected in vega, which is consistent with my expectations. Moreover, vega is positively correlated with and firm size, which are consistent with prior literature. The coefficient on long-term debt ratio is positive and significant. It implies that higher long-term debt ratio attribute to higher vega. The coefficient on growth opportunity is positive and significant, indicating higher growth opportunity is associated with higher vege. Finally, in this study, I find the coefficient on firm risk is positive and significant. It implies that higher risk level of firm will induce higher managerial incentives, which cause higher vega. From the equation of delta, delta depends positively on vega. Delta is also positively correlated with stock price and negatively correlated with firm size. These findings are consistent with Guay $(1999,2002)$ among the others.

Table 2. Simultaneous Equations (3SLS): Firm risk and CEO compensation structure

\begin{tabular}{|c|c|c|c|}
\hline Variables & Risk & Vega & Delta \\
\hline \multicolumn{4}{|c|}{ CEO compensation measures } \\
\hline \multirow[t]{2}{*}{ Vega } & $0.176^{* * * *}$ & & $1.862 * * *$ \\
\hline & $(0.032)$ & & $(0.053)$ \\
\hline \multirow[t]{2}{*}{ Delta } & $-0.078 * * *$ & $0.532 * * *$ & \\
\hline & $(0.052)$ & $(0.041)$ & \\
\hline \multirow[t]{2}{*}{ Risk } & & $3.125 * * *$ & $2.258 * *$ \\
\hline & & $(1.046)$ & $(0.062)$ \\
\hline \multicolumn{4}{|l|}{ Control variables } \\
\hline \multirow[t]{2}{*}{ Long-term debt ratio } & & $3.368 * * *$ & \\
\hline & & $(0.024)$ & \\
\hline \multirow[t]{2}{*}{ Growth opportunities } & & $3.136 * * *$ & \\
\hline & & $(0.051)$ & \\
\hline \multirow[t]{2}{*}{ Firm size } & $0.364 * * *$ & $2.598 * * *$ & $-3.338 *$ \\
\hline & $(0.023)$ & $(0.009)$ & $(0.052)$ \\
\hline \multirow[t]{2}{*}{ Stock prices } & & & $0.482 * * *$ \\
\hline & & & $(0.037)$ \\
\hline
\end{tabular}

\begin{tabular}{ll}
\hline Governance Structure & \\
\hline State ownership & $-3.258^{* * *}$ \\
& $(0.016)$ \\
Ownership concentration & $-2.882^{* * *}$ \\
& $(0.037)$ \\
Foreign shares & $4.115^{* * *}$ \\
& $(0.036)$ \\
Board size & $3.272^{* * *}$ \\
& $(0.019)$
\end{tabular}

\begin{tabular}{lccc}
\hline Dummy variables & & & \\
\hline Year dummies & YES & YES & YES \\
Industry dummies & YES & YES & YES \\
\hline R-square & 0.453 & 0.721 & 0.619 \\
\hline
\end{tabular}

Robust standard errors are reported in the parentheses. $* * *, * *$, and * indicate statistical significance at the $1 \%, 5 \%$ and $10 \%$ levels, respectively.

The coefficient on State Ownership is negative and significant. It implies that the CEOs in the state owned firm has less incentive pay structure, so the vega is lower in state owned firm. This finding is consistent with prediction. 
Similarly, ownership concentration is negatively correlated with vega, indicating the more concentration in ownership the less CEO incentive payment thus lower vega. However, Foreign Shares and Board Size are positively correlated with vega. It implies that the firm that has more foreign shares has higher CEO incentive pay thus higher vega; firm with larger board size has more CEO incentive pay thus higher vega. These findings are consistent with prediction. All coefficients are significant.

Table 3. Simultaneous Equations (3SLS): Firm Performance and CEO compensation structure

\begin{tabular}{|c|c|c|c|}
\hline Variables & ROA & Vega & Delta \\
\hline \multicolumn{4}{|c|}{ CEO compensation measures } \\
\hline Vega & $\begin{array}{l}0.692 * * * \\
(0.036)\end{array}$ & & $\begin{array}{l}1.361 * * * \\
(0.046)\end{array}$ \\
\hline Delta & $\begin{array}{l}0.125 * * * \\
(0.062)\end{array}$ & $\begin{array}{l}0.576 * * * \\
(0.043)\end{array}$ & \\
\hline ROA & & $\begin{array}{l}1.159 * * * \\
(1.036)\end{array}$ & $\begin{array}{l}2.468^{* *} \\
(0.029)\end{array}$ \\
\hline \multicolumn{4}{|l|}{ Control variables } \\
\hline Long-term debt ratio & & $\begin{array}{l}4.413 * * * \\
(0.052)\end{array}$ & \\
\hline Growth opportunities & & $\begin{array}{l}3.241 * * * \\
(0.036)\end{array}$ & \\
\hline Firm size & $\begin{array}{l}0.682 * * * \\
(0.039)\end{array}$ & $\begin{array}{l}2.587 * * * \\
(0.043)\end{array}$ & $\begin{array}{l}-4.112 * \\
(0.038)\end{array}$ \\
\hline Stock prices & & & $\begin{array}{l}0.412 * * * \\
(0.037)\end{array}$ \\
\hline \multicolumn{4}{|l|}{ Governance Structure } \\
\hline State ownership & & $\begin{array}{l}-3.336 * * * \\
(0.068)\end{array}$ & \\
\hline Ownership concentration & & $\begin{array}{l}-2.358 * * * \\
(0.019)\end{array}$ & \\
\hline Foreign shares & & $\begin{array}{l}3.758 * * * \\
(0.053)\end{array}$ & \\
\hline Board size & & $\begin{array}{l}2.762 * * * \\
(0.049)\end{array}$ & \\
\hline Dummy variables & & & \\
\hline Year dummies & YES & YES & YES \\
\hline Industry dummies & YES & YES & YES \\
\hline R-square & 0.513 & 0.698 & 0.735 \\
\hline
\end{tabular}

Robust standard errors are reported in the parentheses. ***, **, and * indicate statistical significance at the $1 \%, 5 \%$ and $10 \%$ levels, respectively.

Table 3 reports the 3SLS model for the jointly determined variables on vega, delta, and firm performance (ROA). The coefficients on both vega and delta are positive and significant. It implies that increase CEO incentive compensation as indicated as vega and delta is positively associated with firm performance. Firm size is positively correlated with firm ROA, which is consistent with literature. For relation between vega and delta, vega is significantly positively correlated with delta as predicted. The coefficients on ROA is positive and significant different from zero. It implies that higher level of firm performance increase the managerial incentive in compensation, as reflected in vega, which is consistent with my expectations. Moreover, vega is positively correlated 
with firm size which are consistent with prior literature. From the equation of delta, delta depends positively on vega. Delta is also positively correlated with stock price and negatively correlated with firm size. As firms expand and have higher level of return as reflected on higher ROA, CEO incentive compensation should be higher. Therefore, ROA should be positively related to vega and delta. The regression results in Table 3 are consistent with predictions. The estimated coefficient on vega is positive and is significant at $5 \%$ level. It suggests that higher vega induce higher performance of the firm. On the other hand, higher delta implements higher level of firm performance. The coefficient on delta is positive and significant. The empirical results on governance structure are consistent with the results in Table 2. In particularly, the coefficient on State Ownership is negative and significant. It implies that the CEOs in the state owned firm has less incentive pay structure, so the vega is lower in state owned firm. This finding is consistent with prediction. Similarly, ownership concentration is negatively correlated with vega, indicating the more concentration in ownership the less CEO incentive payment thus lower vega. However, Foreign Shares and Board Size are positively correlated with vega. It implies that the firm that has more foreign shares has higher CEO incentive pay thus higher vega; firm with larger board size has more CEO incentive pay thus higher vega. These findings are consistent with prediction.

Table 4. Simultaneous Equations (3SLS): Firm performance measure (Return) and CEO compensation structure

\begin{tabular}{llll}
\hline Variables & Return & Vega & Delta \\
\hline CEO compensation measures & & & \\
\hline Vega & $0.579^{* * *}$ & & $1.368^{* * * *}$ \\
& $(0.068)$ & & $(0.042)$ \\
Delta & $0.412^{* * *}$ & $0.622^{* * * *}$ & \\
& $(0.037)$ & $(0.011)$ & \\
Return & & $3.375^{* * *}$ & $2.217^{* *}$ \\
& & $(1.046)$ & $(0.069)$ \\
\hline Control variables & & & \\
\hline Long-term debt ratio & & $3.321^{* * *}$ & \\
& & $(0.056)$ & \\
Growth opportunities & & $2.732^{* * *}$ & \\
& & $(0.049)$ & $-3.357^{*}$ \\
Firm size & $-0.891^{* * *}$ & $2.556^{* * *}$ & $(0.062)$ \\
& $(0.056)$ & $(0.037)$ & $0.412^{* * *}$
\end{tabular}

\begin{tabular}{ll}
\hline Governance Structure & \\
\hline State ownership & $-2.218^{* * * *}$ \\
& $(0.046)$ \\
Ownership concentration & $-3.319^{* * *}$ \\
& $(0.046)$ \\
Foreign shares & $4.518 * * *$ \\
& $(0.022)$ \\
Board size & $2.388^{* * *}$ \\
& $(0.013)$
\end{tabular}

\begin{tabular}{llll}
\hline Dummy variables & & & \\
\hline Year dummies & YES & YES & YES \\
Industry dummies & YES & YES & YES \\
\hline R-square & 0.432 & 0.619 & 0.756 \\
\hline
\end{tabular}

Robust standard errors are reported in the parentheses. ${ }^{* *}, * *$, and $*$ indicate statistical significance at the $1 \%, 5 \%$ and $10 \%$ levels, respectively. 
Table 4 reports the 3SLS model for the jointly determined variables on vega, delta, and firm performance (Return). The coefficients on both vega and delta are positive and significant. It implies that increase CEO incentive compensation as indicated as vega and delta is positively associated with firm stock return. Firm size is positively correlated with return, which is consistent with literature. For relation between vega and delta, vega is significantly positively correlated with delta as predicted. The coefficients on ROA is positive and significant different from zero. It implies that higher level of stock return increases the managerial incentive in compensation, as reflected in vega, which is consistent with my expectations. Moreover, vega is positively correlated with firm size as predicted. From the equation of delta, delta depends positively on vega. Delta is also positively correlated with stock price and negatively correlated with firm size. As firms expand and have higher level of return, CEO incentive compensation should be higher. Therefore, stock return should be positively related to vega and delta. The regression results in Table 4 are consistent with predictions. The estimated coefficient on vega is positive and is significant at $5 \%$ level. On the other hand, higher delta implements higher level of return. The coefficient on delta is positive and significant. For variables on governance structure, The coefficient on State Ownership is negative and significant, which indicating that the CEOs in the state owned firm has less incentive pay structure, so the vega is lower in state owned firm. Ownership concentration is negatively correlated with vega, therefore the more concentration in ownership the less CEO incentive payment thus lower vega. Foreign Shares and Board Size are positively correlated with vega. It implies that the firm that has more foreign shares has higher CEO incentive pay thus higher vega; firm with larger board size has more CEO incentive pay thus higher vega.

Additionally, for the regressions in both Tables 2, 3 and 4, I include year dummy variables, and I use logarithmic values of vega and delta rather than the raw values. The results on vega are robust to all these alternative specifications.

\section{Conclusion}

In this study I seek to shed some light on top management pay and how corporate governance mechanisms affect CEO compensation in listed firms. In particular, I examine the effect of ownership structure and board structure on the setting of top-level compensation. I find that CEO pay rose sharply over the period 1998 to 2000, and there is considerable variability in pay levels. I find positive relationship between CEO compensation and performance based on return on assets. Ownership structure has a significant influence to pay. In particular, substantial government ownership and concentrated ownership appear to reduce pay levels. The presence of a foreign shareholder is associated with higher CEO pay and this can be attributed to their desire to hire high quality managers and willingness to pay more.

The regression results indicate that under certain types of ownership, compensation varies with performance. I find there are statistically significant pay-performance coefficients when the controlling shareholder is a SOE or private blockholder. In addition, firms with foreign investors have significant pay-performance sensitivities. I believe greater emphasis needs to be given to performance related pay. High pay-performance sensitivities will provide the incentives for CEOs to work harder to increase firm profits and values.

The results provide evidence showing strong link between compensation and performance varies across firms with different ownership structure. Private ownership and control of listed firms enhance the link between firm performance and executive compensation, while government ownership weakens executive pay-performance link and thus makes the firms less effective in solving the conflicts of interests between their shareholders and management. It suggests that top executives in China listed firms that are less state-controlled are more in line with those of the shareholders and thus these companies operate more like firms in the west. This is consistent with the belief that the piecemeal enterprise reform measures adopted in China will need to be supplemented by change in ownership structure in order to ensure success. As such, China may be in treat need for ownership restructuring to fully succeed in transforming its SOEs to efficient modernized corporations, in the direction of converting state shares to public shares.

\section{References}

Allen, M. (1981). Power and privilege in the large corporation: corporate control and managerial Compensation. American Journal of Sociology, 86, 1112-1123. https://doi.org/10.1086/227356

Ball, R., Robin, A., \& Wu, J. (2000). Accounting standards, the institutional environment and issuer incentives: effect on timely loss recognition in China. Asia Pacific Journal of Accounting and Economics, 7, 71-96. https://doi.org/10.1080/16081625.2000.10510579

Barclay, M., Morellect, E., \& Smith, C. (2003). On the debt capacity of growth options. Journal of Business. 
Baysinger, B., \& Butler, H. (1985). Corporate governance and the board of directors: performance effects of changes in board composition. Journal of Law, Economics and Organizations, 1, 101-124.

Bebchuk, L.A., \& Spamann, H. (2009). Regulating bankers' pay. Georgetown Law Journal, 98, 247-287.

Berger, P., Ofek, E., \& Yermack, D. (1997). Managerial entrenchment and capital structure decisions. Journal of Finance, 52, 1411-1438. https://doi.org/10.1111/j.1540-6261.1997.tb01115.x

Bhagat, S., \& Black, B. (1997). Do independent directors matter? Working Paper, University of Colorado, Boulder.

Bhagat, S., \& Welch, I. (1995). Corporate research and development investments: international Comparisons. Journal of Accounting and Economics, 19, 443-47. https://doi.org/10.1016/0165-4101(94)00391-H

Black, F., \& Scholes M. (1973). The pricing of options and corporate liabilities. Journal of Political Economy, 81, 637-654. https://doi.org/10.1086/260062

Boyd, B.K. (1994). Board control and CEO compensation. Strategic Management Journal, 15, 335-344. https://doi.org/10.1002/smj.4250150502

Bushman, R., \& Piotroski, J.D. (2006). Financial reporting incentives for conservative accounting: the influence of legal and political Institutions. Journal of Accounting and Economics, 42, 107-148. https://doi.org/10.1016/j.jacceco.2005.10.005

Byrd, J., \& Hickman, K. (1992). Do outside directors monitor managers? Evidence from tender offer Bids. Journal of Financial Economics, 32, 195-221. https://doi.org/10.1016/0304-405X(92)90018-S

Chen, C.R., Steiner, T.L., \& Whyte, A.M. (2006). Does stock option-based executive compensation induce risk-taking? An analysis of the firming industry. Journal of Firming \& Finance, 30, 915-945.

Chena, C. R., Steinerb, T. L. and Whytec, A. M. (2006, March). Does stock option-based executive compensation induce risk-taking? An analysis of the firming industry. Journal of Firming \& Finance, 30(3), 915-945.

Coles, J.L., Daniel, N.D., \& Naveen, L. (2006). Managerial incentives and risk-taking. Journal of Financial Economics, 79, 431-468. https://doi.org/10.1016/j.jfineco.2004.09.004

Core, J., \& Guay, W. (1999). The use of equity grants to manage optimal equity incentive levels. Journal of Accounting and Economics, 28, 151-184. https://doi.org/10.1016/S0165-4101(99)00019-1

Core, J., \& Guay, W. (2002a). Estimating the value of employee stock option portfolios and their sensitivities to price and volatility. Journal of Accounting Research, 40, 613-630. https://doi.org/10.1111/1475-679X.00064

Crystal, G. (1991). In search of excess: the overcompensation of American executives. W.W. Norton and Company, New York.

Fama, E.F., \& Jensen, M.C. (1983). Separation of ownership and control. Journal of Law and Economics, 26, 301-325. https://doi.org/10.1086/467037

Finkelstein, S., \& Hambrick, D. (1989). Chief executive compensation: a study of the intersection of markets and political processes. Strategic Management Journal, 10, 121-134. https://doi.org/10.1002/smj.4250100203

Guay, W. (1999). The sensitivity of CEO wealth to equity risk: an analysis of the magnitude and determinants. Journal of Financial Economics, 53, 43-71. https://doi.org/10.1016/S0304-405X(99)00016-1

Hagendorff, J., Collins, M., \& Keasey, K. (2007). Bank governance and acquisition performance. Corporate Governance: An International Review, 15, 957-968. https://doi.org/10.1111/j.1467-8683.2007.00601.x

Hallock, K.F. (1997). Reciprocally interlocking boards of directors and executive compensation. Journal of Financial and Quantitative Analysis, 32, 331-344. https://doi.org/10.2307/2331203

Hermalin, B., \& Iisbach, M. (1991). The effects of board composition and direct incentives on firm Performance. Financial Management, 20, 101-112. https://doi.org/10.2307/3665716

Holderness, C., \& Sheehan, D. (1988). The role of majority shareholders in publicly-held corporations: an $\begin{array}{lllll}\text { exploratory analysis. Journal of Financial Economics, } 20, & 317-346 .\end{array}$ https://doi.org/10.1016/0304-405X(88)90049-9

Jensen, M., \& Murphy, K. (1990). Performance pay and top-management incentives., Journal of Political Economy, 98, 225-264. https://doi.org/10.1086/261677 
John, K., Saunders, A., \& Senbet, L.W. (2000). A theory of firm regulation and management Compensation. Review of Financial Studies, 13, 95-125. https://doi.org/10.1093/rfs/13.1.95

John, T., \& John, K. (1993). Top-management compensation and capital structure. Journal of Finance, 48, 949-974. https://doi.org/10.1111/j.1540-6261.1993.tb04026.x

Kato, T. K., \& Long, C. S. (2006). Executive compensation, firm performance, and corporate governance in China: evidence from firms listed in the Shanghai and Shenzhen stock exchanges. Economic Development and Cultural Change, 54, 945-983. https://doi.org/10.1086/503583

Laeven, L., \& Levine, R. (2009, August). Firm governance, regulation and risk taking. Journal of Financial Economics, 93(2), 259-275. https://doi.org/10.1016/j.jfineco.2008.09.003

Lambert, R., Larcker, D., \& Iigelt, K. (1993). The structure of organizational incentives.Administrative Science Quarterly, 38, 438-461. https://doi.org/10.2307/2393375

Merton, R. (1973). Theory of rational option pricing. Bell journal of Economics and Management Science, 4, 141-183. https://doi.org/10.2307/3003143

Opler, T., Pinkowitz, R., Stulza, R., \& Williamson, R. (1999). The determinants and implications of corporate cash holdings. Journal of Financial Economics, 52, 3-46. https://doi.org/10.1016/S0304-405X(99)00003-3

Palvia, A. (2011). Banks and managerial discipline: does regulatory monitoring play a role? The Quarterly Review of Economics and Finance, 51, 56-68. https://doi.org/10.1016/j.qref.2010.10.003

Pathan, S. (2009, July). Strong boards, CEO power and firm risk-taking. Journal of Firming \& Finance, 33(7), 1340-1350.

Rajgopal, S., \& Shevlin, T. (2002). Empirical evidence on the relation between stock option compensation and risk taking. Journal of Accounting and Economics, 33, 145-171. https://doi.org/10.1016/S0165-4101(02)00042-3

Rogers, D. (2002). Does executive portfolio structure affect risk management? CEO risk-taking incentives and corporate derivatives usage. Journal of Firming and Finance, 26, 271-295. https://doi.org/10.1016/S0378-4266(01)00222-9

Rosenstein, S., \& Wyatt, J. (1990). Outside directors, board independence and shareholder wealth. Journal of Financial Economics, 26, 175-191. https://doi.org/10.1016/0304-405X(90)90002-H

Sawa, T. (1969). The exact sampling distribution of ordinary least squares and two stage least squares estimators. Journal of the American Statistical Association, 64, 923-937. https://doi.org/10.1080/01621459.1969.10501024

Servaes, H. (1994). Do takeover targets overinvest? Review of Financial Studies, 7, 253-277. https://doi.org/10.1093/rfs/7.2.253

Yang, X. (2010, December). Firm risk-taking investments and managerial incentives. Firming and Finance Review, 2(2), 73-87.

Yermack, D. (1996). Higher market valuation for firms with a small board of directors. Journal of Financial Economics, 40, 185-211. https://doi.org/10.1016/0304-405X(95)00844-5 